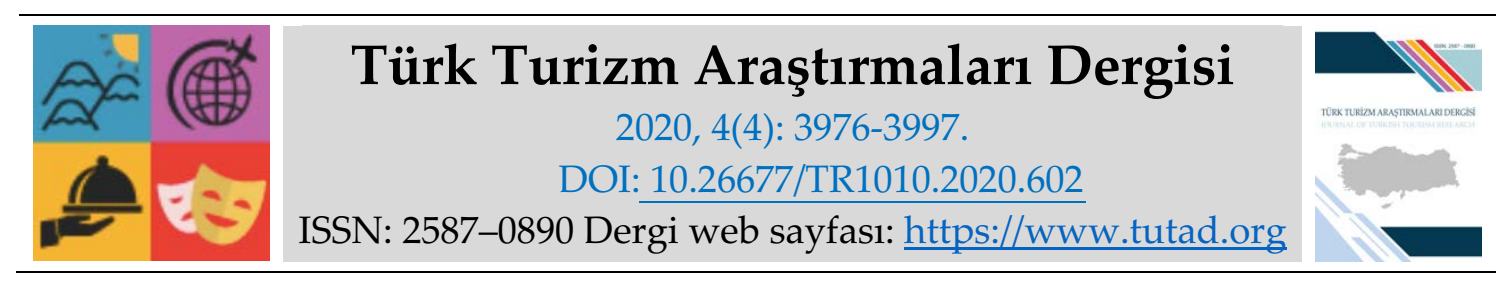

ARASTIRMA MAKALESI

\title{
Algılanan Hizmet Kalitesinin Algılanan Değer ve Davranışsal Niyet Üzerine Etkisi
}

Dr. Öğr. Üyesi Tuğrul AYYILDIZ, Aydın Adnan Menderes Üniversitesi, Turizm Fakültesi, Aydın, e-posta: tugrulayyildiz@gmail.com

ORCID: https://orcid.org/0000-0001-6332-975X

Öz

Günümüzde işletmeler ürünlerinin yanında sundukları hizmet kalitesiyle rekabette ön plana çıkmaya çalışmaktadırlar. Hizmet sektörü içerisinde yer alan otel işletmeleri için verilen hizmetin kalitesi daha da önemli bir hal almıştır. Otel işletmeleri verdikleri hizmet kalitesi ile birlikte müşterilerinin işletmelerinde algıladıkları değeri arttırma çabası içerisindedirler. Böylece bu durum tekrar ziyaret etme, tavsiye etme ve olumlu görüş bildirme gibi davranışsal niyetlerine de yansımaktadır. Bu doğrultuda bu çalışmanın temel amacı algılanan hizmet kalitesinin algılanan değer ve davranışsal niyet üzerine etkisini ortaya koymaktır. Bu temel amaca ek olarak algılanan değerin davranışsal niyet üzerine etkisi de ortaya konmuştur. Araştırmada veri toplama tekniği olarak anket kullanılmıştır. Araştırma için toplam 388 müşteriden anket toplanmıştır. Araştırma sonuçlarına göre hizmet kalitesinin tüm boyutlarının algılanan değer de ise düşük kalite dışındaki tüm boyutların davranışsal niyet üzerinde etkili olduğu saptanmıştır. Analiz sonuçlarına göre hizmet kalitesinin tüm boyutları algılanan değerin kalite-duygusal boyutu üzerinde etkili iken hizmet kalitesinin otel ambiyansı boyutu algılanan değerin finansal-sosyalepistemik ve itibar boyutları üzerinde etkisi bulunmamaktadır. Ayrıca hizmet kalitesi boyutları ile algılanan değer boyutlarından düşük kalite boyutu dışındaki boyutlarla kurulan regresyon modeli anlamlı çıkmıştır.

Anahtar Kelimeler: Hizmet Kalitesi, Algılanan Değer, Davranışsal Niyet.

Makale Gönderme Tarihi: 08.08.2020

Makale Kabul Tarihi: 10.10 .2020

\section{Önerilen Atıf:}

Ayyıldız, T. (2020). Algılanan Hizmet Kalitesinin Algılanan Değer ve Davranışsal Niyet Üzerine Etkisi, Türk Turizm Araştırmaları Dergisi, 4(4): 3976-3997.

(C) 2020 Türk Turizm Araştırmaları Dergisi. 


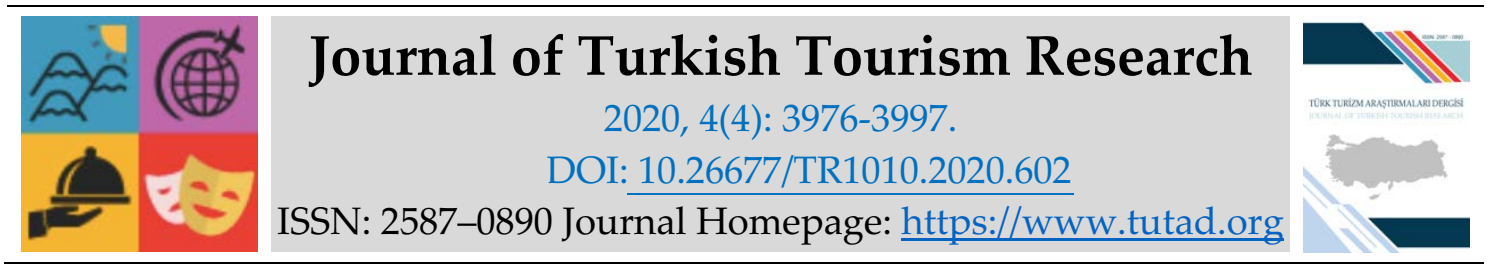

\title{
$\underline{\text { RESEARCH PAPER }}$
}

\section{The Effect of Perceived Service Quality on Perceived Value and Behavioral Intention}

Assistant Prof. Dr. Tuğrul AYYILDIZ, Aydın Adnan Menderes University, Faculty of Tourism, Aydın, e-mail: tugrulayyildiz@gmail.com ORCID: https://orcid.org/0000-0001-6332-975X

\begin{abstract}
Today, enterprises try to come into prominence in the competition with the service quality they offer as well as their products. The quality of the service provided for hotel enterprises within the service sector has become even more significant. Hotel enterprises make great effort to increase the value perceived by their customers in their enterprises together with the service quality they provide. Hence, this situation is reflected in the customers' behavioral intentions such as revisiting, recommending and expressing positive views. In this regard, the main purpose of this study was to reveal the effect of the perceived service quality on the perceived value and behavioral intention. In addition to this basic purpose, the effect of the perceived value on behavioral intention was also revealed. In the research, questionnaire was used as the data collection technique. For the research, the questionnaire was collected from 388 customers in total. As a result of the research, it was determined that all the dimensions of service quality had an effect on behavioral intention, whereas all the dimensions of perceived value other than low quality dimension had an effect on behavioral intention. As a result of the analyzes, it was determined that all the dimensions of service quality had an effect on quality-emotional dimension of perceived value, while the hotel ambiance dimension of the service quality had no effect on the financial-social-epistemic and reputation dimensions of the perceived value. Furthermore, the regression model established with the dimensions of service quality and the dimensions of perceived value other than low quality dimension was found significant.
\end{abstract}

Keywords: Service Quality, Perceived Value, Behavioral Intention.

Received: 08.08.2020

Accepted: 10.10 .2020

\section{Suggested Citation:}

Ayyıldız, T. (2020). The Effect of Perceived Service Quality on Perceived Value and Behavioral Intention, Journal of Turkish Tourism Research, 4(4): 3976-3997.

(c) 2020 Türk Turizm Araştırmaları Dergisi. 


\section{Gíriş}

Turizm endüstrisi, gelişmiş ve gelişmekte olan bir ekonominin üç ana endüstriyel bileşeninden biri olan hizmet endüstrisinin büyümesinde kilit bir itici güç olarak tanımlanmaktadır. Giderek daha rekabetçi bir hale gelen hizmet pazarında, bir hizmet kuruluşu için en önemli ilkelerden biri, uzun vadeli çıkarlarını korumak için müşterileriyle sürekli bir ilişki sürdürmektir. Bu rekabet ortamı göz önünde bulundurulduğunda, hizmet sağlayıcıların kendilerini diğerlerinden farklılaştıracak stratejiler planlamasına ihtiyaç bulunmaktadır. Bu durum, üstün hizmet kalitesi sunarak sağlanabilir (Ali, Khan ve Rehman, 2012: 259). Oldukça rekabetçi otel endüstrisinde de hizmet, pazarda sürdürülebilir bir rekabet avantajı elde etmenin en önemli unsurlarından biri haline gelmiştir. Hizmet yöneticilerinin ve akademik araştırmacıların çabaları, müşterilerin hizmet kalitesini nasıl algıladıklarını anlamaya yöneliktir. Müşteriler, hizmetleri satın alma niyetlerine ve hizmet kalitesi algılarına farklı şekillerde katkıda bulunabilecek çeşitli özellikler olarak görme eğilimindedir (Markoviç ve Raspor, 2010: 195). Müşterilerin sunulan hizmetlerden beklentilerini daha önceden belirlemek ve bu beklentileri genellemek pek mümkün değildir. Ancak bireyden bireye farklılık gösteren bu beklentileri önceden tahmin etmek ve bu tahminler doğrultusunda hizmet kalitesini arttırmaya çalışmak işletmelerin diğer işletmelere göre daha fazla tercih edilir olmasına ve rakipleri ile aralarında fark oluşturmalarına katkı sağlayacaktır (Sevgi ve Paksoy, 2018: 56).

Algılanan değer kavramı hem araştırmalarda hem de uygulamada gün geçtikçe daha önemli bir hale gelmektedir. Örneğin, Amerikan Pazarlama Derneği yakın zamanda "pazarlama" tanımını müşteri değeri kavramını kapsayacak şekilde revize etmiştir. Literatürde, algılanan değerin oynadığı merkezi rol hakkında önemli tartışmalar yaşanmıştır. Algılanan değerin belirlenmesi ve yaratılması, işletmelerin uzun vadeli ayakta kalması ve başarısı için temel bir ön koşul olarak kabul edilir. Müşterilerin bir hizmeti veya ürünü değerlendirmelerini ve değer verme şekillerini anlamak, rekabet avantajı elde etmek için çok önemlidir (Graf ve Mass, 2008: 2). Tüketiciler satın aldıkları ürünlerde bir değer bulmaya çalışırlar. Genel anlamda değer, ödenen maliyetlere göre alınan faydaları ifade etmektedir. Tüketici mallarında, faydalar, ürün kalitesini, ürünün özelliklerini veya niteliklerini ve ürünün uygunluğunu içerir. İşletmelerde, müşterilerin algıladıkları değeri ve müşterilerin bağlılığını artırmak için bu özelliklere yatırım yapar (Gwin, 2009). İlgili literatür tarandığında yapılan çalışmalarda algılanan hizmet kalitesinin algılanan değeri etkilediği görülmektedir (Bauer, Falk ve Hammerschmidt, 2006: 866; Kuo, Wu ve Deng, 2009:888; Ishaq, 2012: 27).

Tüketici davranışının göstergelerini anlamak için Planlı Davranış Teorisi çoğunlukla teorik bir temel olarak kullanilır. Bu teoride Fishbein ve Ajzen $(1975,1980)$, bireylerin sosyal olarak ilgili davranışlarını kontrol ettiklerini ve bu davranışın bir itici gücünün de bu davranışa dahil olma niyetleri olduğunu ileri sürmektedir (Bashir vd., 2019: 1). Davranışsal niyetler, gerçek davranışın sağlam bir öngörücüsüdür. Satın alma, yeniden satın alma, sadakat ve ağızdan ağza iletişim ile ilgili davranışlar savranışsal niyetin içeriğinde bulunmaktadır (Haddad, Hallak ve Assaker, 2015: 265). Hizmet kalitesi ve davranışsal niyetler arasındaki ilişkiler, işletmelerin ve akademik araştırmacıların önemli bir stratejik odak noktası olmuştur. Bu kavramlar arasındaki nedensel ilişkiler, hizmet kalitesinin iyileştirilmesi ve daha yüksek memnuniyet seviyelerinin geliştirilmesi, sonuçta tekrar eden ziyaretçilerin sayısını artırabilecektir. Literatürde, bazı çalışmalar hizmet kalitesi ile davranışsal niyetler arasında olumlu ilişkiler olduğunu bildirmektedir (Lee, Graefe ve Burns, 2004: 76). Ayrıca Petrick (2004)'e göre kalite ve algılanan değer davranışsal niyetlerin iyi birer yordayıcılarıdır (Chen ve Chen, 2010: 31).

Otel işletmeleri müşterilerinin devamını sağlamak ve yeni müşteriler elde etmek adına birçok uygulama gerçekleştirmektedirler. Bunların en önemlisi ise sundukları hizmetin kalitesini 
arttırmaktır. Artan hizmet kalitesi ile birlikte otel müşterilerinin tatminlerinin yükselmesi ve bu doğrultuda algıladıkları değerin artarak davranışsal niyetlere olumlu yansıması olağan bir durum olacaktır. Bu bağlamda çalışmanın temel amacı hizmet kalitesinin algılanan değer ve davranışsal niyet üzerindeki etkisini ortaya koymaktır. Temel amaç çerçevesinde algilanan değerin davranışsal niyet üzerindeki etkisini ortaya koymak alt amaç olarak belirlenmiştir.

\section{KAVRAMSAL ÇERÇEVE}

\section{Hizmet Kalitesi}

Bir hizmet, az veya çok soyut nitelikte bir faaliyet veya faaliyetler dizisidir. Normalde, ancak zorunlu olmamakla birlikte, müşteriler ile hizmet çalışanları ve/veya fiziksel kaynaklar veya hizmet sağlayıcının malları ve/veya sistemleri arasındaki etkileşimlerde gerçekleşir. Hizmetler için kalite değerlendirmesi hizmet sunum sürecinde gerçekleşir. (Arulkumar, 2015: 52). Hizmet kalitesi, rekabet gücünün kritik bir belirleyicisi olarak kabul edilir. "Hizmet kalitesine" dikkat edilmesi, bir kuruluşun kendisini diğer kuruluşlardan farklılaştırmasına ve bu sayede kalıcı bir rekabet avantajı elde etmesine yardımcı olabilir. Üstün "hizmet kalitesi", iş yapmanın maliyeti değil, kârlılığın artması için bir anahtardır (Ghobadian, Speller ve Jones, 1994: 44). Hizmet kalitesi üzerine yapılan pek çok araştırmaya rağmen, literatürün büyük bir kısmı, tüketicinin hizmet kalitesinin genel değerlendirmesini yapmak için öncüllerden ziyade, hizmet kalitesiyle ilişkili faktörleri yapının boyutları veya bileşenleri olarak kavramsallaştırmaya devam etmektedir (Dabholkar, Shepherd ve Thorpe, 2000: 140).

Kalite, genel olarak üstünlük ve mükemmellik olarak tanımlanabilir. Sonuç olarak, algılanan kalite, tüketicinin bir ürünün genel mükemmelliği ve üstünlüğü hakkındaki yargıları olarak tanımlanabilir (Zeithaml, 1988: 3). Verilen bir hizmetin algılanan kalitesinin, tüketicinin beklentilerini aldığı hizmetle karşılaştırdığı, yani algılanan hizmeti beklenen hizmetin karşısına koyduğu bir değerlendirme sürecinin sonucu olacağını belirtmek mantıklıdır. Bu sürecin sonucu, hizmetin algilanan kalitesi olacaktır (Grönroos, 1984: 37). Algılanan hizmet kalitesi, tüketicilerin algıları ve beklentileri arasındaki farkın derecesi ve yönü olarak belirlenmektedir. Hizmet kalitesi literatüründe beklentiler, tüketicilerin istediği arzular, yani bir hizmet sağlayıcının sunmaktan çok sunması gerektiğini düşündükleri şeyler olarak görülmektedir (Parasuraman, Zeithaml ve Berry, 1988: 17). Algılanan hizmet kalitesi bir tutum biçimi, uzun vadeli genel bir değerlendirmedir (Cronin ve Taylor, 1992: 56).

Hizmet kalitesi ile ilgili yapılan çalı̧̧malarda hizmet kalitesini ölçmek üzere farklı ölçekler kullanılmıştır (Grönross, 10984:38; Parasuraman, Zeithaml ve Berry, 1985: 47; Parasuraman, Zeithaml ve Berry, 1988: 23). Grönross (1984) 'a göre algılanan hizmet, tüketicinin, bazıları teknik, bazıları doğası gereği işlevsel olan bir dizi hizmet boyutuna ilişkin görüşünün sonucudur. Grönross yapmış olduğu çalışmada algılanan hizmet kalitesini teknik kalite ve işlevsel kalite olarak 2 boyutta belirlemiş̧tir (Grönross, 1984: 38). Parasuraman, Zeithaml ve Berry (1985) yapmış oldukları çalışmada GAP modeli ile hizmet kalitesinin Güvenilirlik, yanıt verebilirlik, yeterlilik, erişim, nezaket, iletişim, güvenilirlik, güvenlik, müşteriyi anlama, somut özellikler olmak üzere 10 boyutunu ortaya koymuşlar (Parasuraman, Zeithaml ve Berry, 1985: 47) aynı bilim insanları 1988 yılında yaptıkları çalışmada SERVQUAL ölçeğini geliştirerek hizmet kalitesinin somut özellikler, güvenilirlik, heveslilik, güven ve empati olmak üzere 5 boyutunu ortaya koymuşlardır (Parasuraman, Zeithaml ve Berry, 1988: 23). Operasyonel düzeyde, hizmet kalitesindeki araştırmalar, GAP modeline dayanan SERVQUAL aracının hakimiyetindedir. Bu modeldeki ana fikir, hizmet kalitesinin, beklentiler ve algılar arasındaki fark puanlarının veya boşlukların bir işlevi olduğudur (Bloemer, Ruyter ve Wetzels, 1999: 1084). Mei Dean ve White (1999) konaklama 
işletmelerinde yapmış oldukları çalışma ile HOLSERV ölçeğini geliştirerek hizmet kalitesini çalışlanlar, fiziksel özellikler ve güvenilirlik olmak üzere 3 boyutta ele almışlardır (Mei, Dean ve White, 1999: 140). Saleh ve Ryan yapmış oldukları çalışmada şenlik, somut şeyler, güvence, alaydan kaçınma, empati olmak üzere 5 hizmet kalitesi boyutunu ortaya koymuştur (Saleh ve Ryan, 1991: 338). Amin vd., (2013) ayrıca Malezya Otel Endüstrisinde hizmet kalitesinin beş boyutunu da test etmiş ve (1) otel ortamı ve personel nezaketi, (2) yiyecek ve içecek ürün ve hizmet kalitesi, (3) personel sunumu ve bilgisi, (4) rezervasyon hizmetleri ve (5) paranın genel değeri olmak üzere 5 boyut ortaya koymuşlardır (Amin vd., 2013: 121; Ali, 2015: 40).

\section{Algılanan Değer}

Ekonomik terimlerle ifade edersek, 'değer' geleneksel olarak fayda ya da istenirlik ile eşitlenmiştir. Bu bağlamda, 'fayda teorisi', değer yapısının kavramsal temelini sağlar. Bu teori, tüketicilerin, bir ürünün özelliklerinin sağladığı "fayda" ile ödenen fiyatla temsil edilen "uyumsuzluk" arasındaki farka göre değer türettiklerini savunur. Bu yaklaşımı benimseyen birçok yazar, algılanan değer tanımlarında (çeşitli şekillerde) "fayda" terimini kullanmıştır (Sanchez-Fernandez ve Iniesta-Bonillo, 2007: 429). Algilanan değer, müşteriye değer yaratmak, iletmek ve müşteriye değer sunmak için yönetim stratejilerinin geliştirilmesinde önemli bir kriter haline gelmiştir (Yu vd., 2014: 759).

Kesin bir değer tanımı gerçekleştirme arayışı birçok araştırmacı için zorlu bir görev olarak görülmektedir. Değer, tüketim deneyiminin temel bir sonucu olarak kabul edilir ve yapının kavramsallaştırmaları, belirli bir çalışmanın bağlamına göre değişebilir (LeBlanc ve Nguyen, 1999: 188). Algılanan değer, satın alma davranışını tahmin etmek için istikrarlı bir yapı olarak önemli araştırma ilgisi kazanmıştır. Algılanan değer çok çeşitli şekillerde tanımlanmıştır, değer kavramı çok yönlüdür ve çok sayıda yorum, önyargı ve vurgu ile karmaşıktır. Zeithaml (1988) değeri, tüketicinin neyin alındığı ve neyin verildiği algılarına dayalı olarak bir ürünün faydasına ilişkin genel değerlendirmesi olarak tanımlamıştır. Müşterilerin bir hizmeti kullanarak aldıkları veya deneyimledikleri değerdir (Hu, Kandampully ve Juwaheer, 2009: 114). Zeithalm (1988)'1n yaptığı bu tanım, maddi malın (örneğin kalite) elde ettiği faydaların yanı sıra markayla bir ilişki veya yakınlıktan kaynaklanabilecek maddi olmayan faydaları da içerir (Gwin, 2009: 529). Parasuraman ve diğerleri (1985), bir ürün veya hizmetin değer sağlayıp sağlamadığını yalnızca müşterinin değerlendirebileceğini ve müşteri tarafından algılanan değer kavramının çok öznel ve kişisel olarak algılandığını belirtir. Vandermerwe (2003) bu görüşü desteklemekte ve müşteriler toplam deneyimden memnun olduğunda değerin müşteriler tarafından tanımlanması gerektiğini anlatmaktadır (Ali, Omar ve Amin 2013: 12).

Algılanan değer konusunda farklı bilim insanları farklı ölçekler geliştirmişlerdir. algılanan değer ile ilgili ölçümler tek boyutlu ve çok boyutlu olarak gerçekleştirilmiştir. Tek boyutlu yaklaşım genel anlamda tamamıla algılanan müşteri değerini ölçmektedir. Çok boyutlu yaklaşım ise; algılanan değeri getirdiği fayda (ekonomik, sosyal ve ilişkisel) ve bunun karşıllğında katlanılan fedakârlık (fiyat, zaman, çaba, risk ve uyum) boyutları ile ölçmektedir (Türkmendağ ve Köroğlu, 2018: 1125). Çok boyutlu ilk ölçeklerden biri Sheth, Newman ve Gross (1991)'e aittir. Bilim insanları yaptıkları çalışmada algılanan değeri duygusal, şartsal, sosyal, işlevsel ve Epistemik değer olmak üzere 5 boyutta ölçmüşlerdir (Sheth, Newman ve Gross, 1991: 165). Bir malın satın alma sonrası algılanan değerine atıfta bulunmasına rağmen, bir ölçeğin geliştirilmesine odaklanan en metodolojik desteğe sahip önerilerden biri, PERVAL'i geliştiren Sweeney ve Soutar (2001)' 1 önerisidir (Sanchez vd., 2006: 396). Sweeney ve Soutar (2001) PERVAL ölçeğini sosyal, kalite, duygusal ve fiyat olmak üzere 4 boyuttan oluştuğunu ortaya koymuşlardır (Sweeney ve Soutar, 2001: 212). SERV-PERVAL ölçeğini geliştiren Petrick (2002) ise algılana değeri kalite, 
duygusal tepki, parasal fiyat, davranışsal fiyat ve itibar olmak üzere 5 boyutta ölçmüştür. Sanchez ve arkadaşları (2006) yılında geliştirdikleri GLOVAL ölçeği ile algılanan değeri (1) seyahat acentesinin işlevsel değeri (tesisler); (2) seyahat acentesinin irtibat personelinin işlevsel değeri (profesyonellik); (3) satın alınan turizm paketinin işlevsel değeri (kalite); (4) işlevsel değer fiyatı; (5) duygusal değer ve (6) sosyal değer olmak üzere 6 boyutta ölçmüşlerdir (Sanchez vd., 2006: 401).

Algılanan değerin, hizmet kalitesi ile yüksek oranda ilişkili olduğu varsayılır (Tam, 2000: 32). Lovelock vd. (2005) hizmet kalitesinin algılanan değeri etkileyen önemli faktörlerden biri olduğuna işaret etmektedir ( $\mathrm{Wu}, 2014:$ 542). Algılanan değer, bir tüketicinin deneyiminin değerlendirilmesi ve gerçek maliyet ile algılanan fayda arasındaki uyuşmazlık ortaya konarak ölçülür. Algilanan değer hizmet kalitesinin, müşteri memnuniyetinin ve davranışsal niyetin değerlendirilmesinde önemli bir rol oynar (Yu vd., 2014: 759). Algılanan değer davranışsal niyetin iyi bir göstergesi durumundadır (Cronin, Brady ve Hult, 2000: 193; Chen ve Chen, 2010: 31). Bu doğrultuda kurulan hipotezler aşağıdaki gibidir.

H1: Algılanan hizmet kalitesi algılanan değeri etkilemektedir.

$\mathrm{H}_{2}$ : Algılanan değer davarnışsal niyeti etkilemektedir.

\section{Davranışsal Niyet}

Davranışsal niyet kavramı Ajzen (1991) tarafından gerçekleştirilen planlanmış davranış teorisine dayanmaktadır. Planlanmış davranış teorisi, insanların eksik irade kontrolüne sahip olduğu davranışları ele alan mantıklı eylem teorisinin bir uzantısıdır. Mantıklı eylem teorisinde ki gibi, planlanmış davranış teorisinde de temel nokta, kişinin belirli bir davranışı gerçekleştirme niyetidir (Baş ve Artuğer, 2018: 761). Ajzen (1985)'e göre genel olarak, Planlı Davranış Teorisi, davranışlar, davranışsal niyetler, tutumlar ve inançları içeren birkaç ilgili çalışma konusuna uygulanabilir (Bashir vd., 2019: 2).

Müşterilerin bir ürün/hizmetle ilgili önceki deneyimleri, hizmet sağlayıcıya karşı bir tutum oluşturmalarına yardımcı olur. Bu tutum, bir ürünü/hizmeti önceki deneyime göre oldukça istikrarlı bir şekilde beğenme/beğenmeme gelişimi olarak tanımlanabilir ve bu tutum, tüketicinin yeniden satın alma ve tavsiye etme niyetleriyle büyük ölçüde ilişkilidir. Oliver (1997), davranışsal niyetleri " bir davranışta bulunma olasılığının belirtilmesi" olarak tanımlamaktadır (Han ve Kim, 2009: 825). Araştırmacılar genel olarak davranışsal niyetlerin kişinin belirli bir davranış sergilemeye hazır olması/olasılığı olduğu konusunda hemfikirdir (Kauar ve Gupta, 2012: 245). Davranışsal niyet tekrar ziyaret etme ve ağızdan ağıza iletişim niyetlerini kapsamaktadır (Jani ve Han, 2011: 1003).

Hizmet kalitesi ile tüketici davranış niyetleri arasında bir bağlantı kurmak, hizmet kalitesi araştırmasının değerinin kanıtı olduğu için araştırmacılar ve uygulayıcılar için önemli bir görevdir (Theodorakis ve Alexandris, 2008: 165). Literatür incelendiğinde hizmet kalitesi ile davranışsal niyet arasında ilişkiyi araştıran bazı araştırmalar bulunmaktadır. Zeithalm, Berry ve Parasuraman, 1996 :31; Lee, Graefe ve Burns, 2004: 73; Ladhari, 2009: 308; Vijayadurai, 2008: 14) Bu doğrultuda kurulan hipotez aşağıdaki gibidir.

$\mathrm{H}_{3}$ : Algılanan hizmet kalitesi davarnışsal niyeti etkilemektedir. 
Genel olarak literatür değerlendirildiğinde hizmet kalitesinin algılanan değer ve davranışsal niyeti etkilediği görülmektedir. Aynı şekilde algılanan değerinde davranışsal niyeti etkilediği literatürde belirtilmektedir.

\section{YÖNTEM}

$\mathrm{Bu}$ araştırma nicel araştırma yaklaşımlarından ilişkisel tarama modeli kullanılarak gerçekleştirilmiştir. İlişkisel tarama modeli birden fazla değişken arasındaki etkileşimlerin ortaya çıarılmasında kullanılır. İlişkisel model değişkenler arasındaki ilişkileri temel alır (Şimşek, 2012: 92). Araştırma kapsamında Kuşadası'ndaki 5 yıldızlı otel işletmelerinde 2019 yılı Eylül-Ekim aylarında konaklama gerçekleştiren müşterilerden anket yolu ile veriler toplanmıştır. Araştırma kapsamında kolayda örnekleme yöntemi kullanılmıştır. Kolayda örnekleme tekniğinde esas olan ankete cevap veren herkesin örneğe dahil edilmesidir. Ulaşabilen ve arzu eden herkes ankete katılabilir (Altunışık, Coşkun, Bayraktaroğlu ve Yıldırım, 2005: 132). Kuşadası'nda toplam 13 adet 5 yıldızlı otel işletmesi bulunmaktadır. Bu işletmelerden 8 tanesi çalışmaya katılmayı kabul ederek müşterilerine anket yapılması konusunda izin vermiştir. Bu 8 işletmede toplam 800 anket müşterilere dağıtılmış ancak 402 anket geriye dönmüştür. Geriye dönüşü olan anketlerden bazılarının oldukça eksik doldurulduğu, bazılarının sadece aynı şık işaretlendiği gibi nedenlerle toplam 14 anket değerlendirme dışı bırakılarak toplamda 388 anket değerlendirmeye alınmıştır. Çalışma kapsamı içerisinde oluşturulan anket toplam 4 bölümden oluşmaktadır. İlk bölümde 4 ifadeden oluşan davranışsal niyet ölçeği yer almaktadır. Davranışsal niyet ölçeği Ali (2015) tarafından gerçekleştirilen "Service Quality as a Determinant of Customer Satisfaction and Resulting Behavioural Intentions: A SEM Approach Towards Malaysian Resort Hotels"başlıklı çalışmadan alınmıştır. Ali yapmış olduğu çalışmada ölçeği Jani ve Han (2011) tarafından gerçekleştirilen "Investigating The Key Factors Affecting Behavioral Intentions Evidence From a Full-Service Restaurant Setting" başlıklı çalışmadan uyarlamıştır. Anketin 2. bölümünde 26 ifadeden oluşan hizmet kalitesi ölçeği yer almaktadır. Hizmet kalitesine yönelik ifadeler Ali (2015) tarafından gerçekleştirilen "Service Quality as a Determinant of Customer Satisfaction and Resulting Behavioural Intentions: A SEM Approach Towards Malaysian Resort Hotels" başlıklı çalışmadan alınmıştır. Ali, yapmış olduğu çalışmada ölçeği Amin, Yahya, Ismayatim, Nasharuddin,ve Kassim, (2013). Service Quality Dimension and Customer Satisfaction: An Empirical Study in the Malaysian Hotel Industry" ve Mohsin ve Lockyer (2010). "Customer Perceptions of Service Quality in Luxury Hotels in New Delhi, India: An Exploratory Study" başlıklı çalışmalardan uyarlamıştır. Anketin 3. Bölümünde 28 ifadeden oluşan algılanan değer ölçeği yer almaktadır. Algılanan değere ifadeler Küpeli (2014) tarafından "Algılanan Risk ve Algılanan Değer Arasındaki İlişkilerin Otel Müşterileri Üzerinde İncelenmesi” başlıklı çalışmasından alınmıştır. Küpeli yapmış olduğu çalışmada ölçeği Sweeney ve Soutar (2001). "Consumer Perceived Value: The Development of a Multiple Item Scale", Williams ve Soutar (2009). "Value, Satisfaction and Behavioral Intentions in An Adventure Tourssm Context" ve Petrick (2004). "The Roles of Quality, Value and Satisfaction in Predicting Cruise Passengers' Behavioral Intentions" başlıklı çalışmalardan uyarlamıştır. Tüm ölçekler 5'li Likert tipi (1Tamamen Katılmıyorum, 5-Tamamen katılıyorum) şeklinde hazırlanmıştır. Anketin son bölümünde katılımcıların cinsiyetlerine, yaşlarına, eğitimlerine, uyruklarına ve daha önce aynı oteli ziyaret edip etmediklerine yönelik sorular sorulmuştur. Oluşturulan anket hem Türkçe hem de İngilizce dillerinde hazırlanmıştır. Anketin Türkçe ve İngilizce çevrilmesinde dil uzmanlarından destek alınmıştır. Araştırma kapsamında elde edilen verilerin analizinde SPSS programı kullanılmıştır. İfadelere ait çarpıklık ve basıklık değerleri hesaplanmış ve $+1,5$ ve $-1,5$ aralığında bulunmuştur. Bu değerler verilerin normal dağılıma sahip olduğunu gösterir (Tabachnick ve Fidell, 2013: 80). 


\section{BULGULAR}

Bu bölümde öncelikle katılımcılara ait özellikler verilmiştir. Daha sonra ölçeklere yapılan faktör analizi, ve hizmet kalitesinin algılanan değer ve davranışsal niyet ile ilişkisini ve üzerindeki etkisini belirlemeye yönelik korelasyon ve regresyon anlizi sonuçları verilmiştir.

\section{Katılımcılara Ait Özellikler}

Katılımcılara ait cinsiyet, yaş, eğitim, daha önce aynı otelde konaklama durumu ve uyruk ile ilgili frekanslar Tablo 1'de verilmiştir.

Tablo 1. Katılımcllara Ait Özellikler

\begin{tabular}{|c|c|c|c|}
\hline Değişken & Grup & Frekans & Yüzde \\
\hline \multirow{3}{*}{ Cinsiyet } & Erkek & 178 & 45,9 \\
\hline & Kadın & 196 & 50,5 \\
\hline & Kayıp Değer & 14 & 3,6 \\
\hline \multirow{5}{*}{ Yaş } & 18-25 & 61 & 15,7 \\
\hline & $26-35$ & 132 & 34,0 \\
\hline & $36-45$ & 109 & 28,1 \\
\hline & $46-55$ & 61 & 15,7 \\
\hline & 56 ve üzeri & 25 & 6,4 \\
\hline \multirow{6}{*}{ Eğitim } & İlköğretim & 10 & 2,6 \\
\hline & Lise & 149 & 38,4 \\
\hline & Üniversite & 170 & 43,8 \\
\hline & Yükseklisans & 35 & 9,0 \\
\hline & Doktora & 4 & 1,0 \\
\hline & Kayıp Değer & 20 & 5,2 \\
\hline \multirow{3}{*}{$\begin{array}{l}\text { Daha Önce Aynı Otelde } \\
\text { Konaklama Durumu }\end{array}$} & Evet & 180 & 46,4 \\
\hline & Hayır & 192 & 49,5 \\
\hline & Kayıp Değer & 16 & 4,1 \\
\hline \multirow{2}{*}{ Uyruk } & Yerli & 157 & 40,5 \\
\hline & Yabanc1 & 231 & 59,5 \\
\hline
\end{tabular}

Tablo 1 incelendiğinde katılımcıların \%50,5'i kadın \%45,9'u erkek katılımcılardan oluşmaktadır. Katılımcların çoğunluğu 26-35 yaş aralığında, üniversite mezunu ve yabancı turistlerden oluşmaktadır. Katılımcıların çoğunluğu çalışmanın yapıldığı andaki konakladıkları otelde ilk defa konaklamaktadırlar.

\section{Davranışsal Niyet Ölçeğine Ait Açımlayıcı Faktör Analizi}

Davranışsal niyet ölçeği Ali (2015) tarafından kullanılan ölçektir. Bu ölçeğin orijinali 4 ifade tek boyuttan oluşmaktadır. Davranışsal niyet ölçeği ile ilgili faktör analizine geçmeden önce davranışsal niyet ile ilgili ifadelere güvenilirlik analizi uygulanmıştır. Gerçekleştirilen güvenilirlik analizi sonucunda davranışsal niyet ölçeğine ait genel güvenilirlik ,932 olarak ortaya çıkmış ve bu değer ölçeğin yüksek düzeyde bir güvenilirliğe sahip olduğunu göstermektedir (Özdamar, 1999: 522). Güvenilirlik analizinden sonra davranışsal niyet ölçeğine bu 4 ifade üzerinden faktör analizi gerçekleştirilmiştir. Yapılan faktör analizi sonucunda Keyser-Meyer-Olkin testi sonucu örneklem yeterlilik değeri 0,834 bulunmuş ve bu değer faktör analizi için uygun bir değer olarak görülmüştür 
(Can, 2014: 303). Faktör analizinde korelasyon matrisinin yeterliliği ve önem düzeyi için Bartlett's Sphericity testi kullanılmıştır. Gerçekleştirilen faktör analizi sonucunda korelasyon matrisinin yeterliliği ve önem düzeyi sırasıyla ,000 ve 758,291 olarak belirlenmiş ve faktör analizi yapmak için bu değerler kabul edilebilir bir değer olarak alınmıştır. Gerçekleştirilen faktör analizi sonucu tek boyut elde edilmiş ve bu boyut orijinal ölçeğe sadık kalınarak davranışsal niyet olarak isimlendirilmiştir.

Tablo 2. Davranışsal Niyet Ölçeğine İlişkin Faktör Analizi

\begin{tabular}{|l|l|l|l|l|}
\hline & $\begin{array}{l}\text { Faktör } \\
\text { yükleri }\end{array}$ & Özdeğer & $\begin{array}{l}\text { Açıklanan } \\
\text { varyans }\end{array}$ & $\begin{array}{l}\text { Cronbach } \\
\text { Alpha }\end{array}$ \\
\hline Davranışsal Niyet & & $\mathbf{3 , 3 2 5}$ & $\mathbf{8 3 , 1 1 4}$ & $\mathbf{0 , 9 3 2}$ \\
\hline $\begin{array}{l}\text { Bu oteli ziyaret etmeye devam etmek } \\
\text { niyetindeyim. }\end{array}$ & 913 & & & \\
\hline $\begin{array}{l}\text { Bu oteli gelecekte ilk tercihim olarak } \\
\text { değerlendiriyorum. }\end{array}$ &, 916 & & & \\
\hline Bu otel hakkında olumlu sözler yayacağım. &, 918 & & & \\
\hline Bu oteli tanıdıklarıma tavsiye ederim. &, 900 & & & \\
\hline
\end{tabular}

Faktör analizi sonucunda değişkenlere ait faktör yük değerleri 0,900 ve üzerinde olarak tespit edilmiştir. Verilerin analizinde varimax rotasyonu kullanılmıştır. Faktör analizinde, öz değerleri 1'in üzerinde olan veriler değerlendirmeye alınmıştır. Gerçekleștirilen faktör analizi sonucunda değişkenlerin tek faktör altında toplandığı görülmektedir. Bu tek faktör toplam varyansın \%83,114'ünü açıklamaktadır. Bu değerler tek faktörün 4 değişken tarafından açıklanan varyansı açılayabildiğini göstermektedir. Bundan sonraki müşteri tatmini ölçeği ile ilgili analizlerde bu tek faktör kullanılmıştır.

\section{Hizmet Kalitesi Ölçeğine Ait Açımlayıcı Faktör Analizi}

Hizmet kalitesi ölçeği Ali (2015) tarafından kullanılan ölçektir. Bu ölçeğin orijinali 26 ifade ve otel ambiyansı ve personel nezaketi, Yiyecek ve içecek ürün ve hizmet kalitesi, Personel sunumu ve bilgisi, Rezervasyon hizmetleri, Paranın genel değeri olmak üzere 5 boyuttan oluşmaktadır. Hizmet kalitesi ölçeği ile ilgili faktör analizine geçmeden önce hizmet kalitesi ile ilgili ifadelere güvenilirlik analizi uygulanmıştır. Gerçekleştirilen güvenilirlik analizi sonucunda hizmet kalitesi ölçeğine ait genel güvenilirlik ,962 olarak ortaya çıkmış ve bu değer ölçeğin yüksek düzeyde bir güvenilirliğe sahip olduğunu göstermektedir (Özdamar, 1999: 522). Daha sonra ölçeğe bu 26 ifade üzerinden faktör analizi uygulanmıştır. Gerçekleştirilen ilk faktör analizi sonucunda 3 ifade faktör yükleri ,50'nin altında olması sebebiyle faktör analizinden çıkarılmıştır. Geriye kalan 23 ifade ile yapılan faktör analizi sonucunda Keyser-Meyer-Olkin testi sonucu örneklem yeterlilik değeri 0,944 bulunmuş ve bu değer faktör analizi için uygun bir değer olarak görülmüştür (Can, 2014: 303). Faktör analizinde korelasyon matrisinin yeterliliği ve önem düzeyi için Bartlett's Sphericity testi kullanılmıştır. Gerçekleştirilen faktör analizi sonucunda korelasyon matrisinin yeterliliği ve önem düzeyi sırasıyla ,000 ve 3321,476 olarak belirlenmiş ve faktör analizi yapmak için bu değerler kabul edilebilir bir değer olarak alınmıştır. Yapılan faktör analizi sonucu 3 boyut bulunmuş ve bu boyutlar personel bilgisi-rezervasyon hizmetleri-paranın genel değeri, çalışan nezaketi- Yiyecek ve içecek ürün ve hizmet kalitesi ve otel ambiyansı olarak isimlendirilmiştir. 
Tablo3: Hizmet Kalitesi Ölçeğine İlişkin Faktör Analizi

\begin{tabular}{|c|c|c|c|c|}
\hline & $\begin{array}{l}\text { Faktör } \\
\text { yükleri }\end{array}$ & Özdeğer & $\begin{array}{l}\text { Açılanan } \\
\text { varyans }\end{array}$ & $\begin{array}{l}\text { Cronbach } \\
\text { Alpha }\end{array}$ \\
\hline $\begin{array}{l}\text { Personel Bilgisi-Rezervayon Hizmetleri-Paranın } \\
\text { Genel Değeri }\end{array}$ & & 12,061 & 52,438 & 0,936 \\
\hline $\begin{array}{l}\text { Bu otelin çalışanlarının davranışları bana güven } \\
\text { veriyor. }\end{array}$ & ,560 & & & \\
\hline $\begin{array}{l}\mathrm{Bu} \text { oteldeki çalışanlar bana sürekli kibar } \\
\text { davranıyor. }\end{array}$ &, 585 & & & \\
\hline Bu otelin çalışanları bana özel ilgi gösteriyor. &, 573 & & & \\
\hline Bu otelin çalışanları özel ihtiyaçlarımı anlıyor. & 697 & & & \\
\hline $\begin{array}{l}\mathrm{Bu} \text { otelde çalışanlar, bana ilgi çekici yerleri } \\
\text { önerebilir. }\end{array}$ & 689 & & & \\
\hline $\begin{array}{l}\text { Bu otel belli bir zamanda bir şeyler yapma sözü } \\
\text { verdiğinde, onu zamanında yapar. }\end{array}$ & 620 & & & \\
\hline $\begin{array}{l}\text { Bu otelde rezervasyonum verimli bir şekilde } \\
\text { gerçekleştirildi. }\end{array}$ & 636 & & & \\
\hline Bu otel, benim çıkarımı düşünüyor. & 612 & & & \\
\hline $\mathrm{Bu}$ otelin hizmetlerinin uygun iş saatleri vardır. & ,638 & & & \\
\hline Bu otel, bireysel ilgi göstermektedir. & ,680 & & & \\
\hline $\begin{array}{l}\text { Bu otelde kaldığım süre boyunca ödediğim } \\
\text { paranın karşılığını aldım. }\end{array}$ & ,766 & & & \\
\hline $\begin{array}{l}\text { Bu otel, hizmet sunarken ilk seferinde doğruyu } \\
\text { yapar. }\end{array}$ & ,744 & & & \\
\hline $\begin{array}{l}\text { Çalışan Nezaketi-Yiyecek ve İçecek Ürün ve } \\
\text { Hizmet Kalitesi }\end{array}$ & & 1.466 & 6,372 & 0,891 \\
\hline $\begin{array}{l}\text { Bu otelin personeli yardımsever ve güler } \\
\text { yüzlüdür. }\end{array}$ & 643 & & & \\
\hline Bu otelde çok ilgi gördüm. & 663 & & & \\
\hline $\begin{array}{l}\text { Bu otelde giriş ve çıkış (check-in check-out) } \\
\text { işlemleri etkindir. }\end{array}$ & 696 & & & \\
\hline $\begin{array}{l}\text { Bu otel menüsünde çeşitli yiyecek ve içecekler } \\
\text { sunmaktadır. }\end{array}$ & 603 & & & \\
\hline $\begin{array}{l}\text { Genel olarak bu otelde içecek seçimi tatmin } \\
\text { edicidir. }\end{array}$ &, 593 & & & \\
\hline Bu otelin restoran yemek kalitesi iyidir. & ,704 & & & \\
\hline Bu otelin çalışanları temiz görünüyor. & ,677 & & & \\
\hline Otel Ambiyansı & & 1.027 & 4,465 & 0,859 \\
\hline Bu otel modern donanıma sahiptir. & ,741 & & & \\
\hline Bu otelin fiziki görünümü çekicidir. & 842 & & & \\
\hline $\begin{array}{l}\text { Bu otelin resepsiyon ve lobisi görsel olarak } \\
\text { çekicidir. }\end{array}$ & ,757 & & & \\
\hline $\begin{array}{l}\text { Bu oteldeki hizmetlerle ilgili materyaller görsel } \\
\text { olarak çekicidir. }\end{array}$ & 674 & & & \\
\hline
\end{tabular}


Faktör analizi sonucunda değişkenlere ait faktör yük değerleri 0,560 ve üzerinde olarak tespit edilmiştir. Verilerin analizinde varimax rotasyonu kullanılmıştır. Faktör analizinde, öz değerleri 1'in üzerinde olan veriler değerlendirmeye alınmıştır. Gerçekleştirilen faktör analizi sonucunda değişkenlerin 3 faktör altında toplandığı görülmektedir. Bu 3 faktör toplam varyansın \%63,275'ini açılamaktadır. Bu değerler 3 faktörün 23 değişken tarafından açıklanan varyansı açıklayabildiğini göstermektedir. Bundan sonraki hizmet kalitesi ölçeği ile ilgili analizlerde bu 3 faktör kullanılmıştır. Bu ölçeğin orijinali 6 boyuttan oluşmaktadır. Ancak gerçekleştirilen faktör analizi sonucunda orijinal ölçeğe göre bazı faktörlerin birleştiği görülmektedir. Bu durum orijinal ölçeğin farklı bir ülkede uygulanması, Kuşadası'ndaki otellerde uygulanan hizmet kalitesi ile bu ülkedeki hizmet kalitesinin farklı olmasından kaynaklanıyor olabilir.

\section{Algılanan Değer Ölçeğine Ait Açımlayıcı Faktör Analizi}

Algılanan değer ölçeği Küpeli (2014) tarafından kullanılan ölçektir. Bu ölçeğin orijinali 28 ifade ve kalite, duygusal, finansal, sosyal, epistemik ve itibar olmak üzere 6 boyuttan oluşmaktadır. Algılanan değer ölçeği ile ilgili faktör analizine geçmeden önce algılanan değer ile ilgili ifadelere güvenilirlik analizi uygulanmıştır. Gerçekleştirilen güvenilirlik analizi sonucunda algılanan değer ölçeğine ait genel güvenilirlik ,955 olarak ortaya çıkmış ve bu değer ölçeğin yüksek düzeyde bir güvenilirliğe sahip olduğunu göstermektedir (Özdamar, 1999: 522). Daha sonra ölçeğe bu 28 ifade üzerinden faktör analizi uygulanmıştır. Gerçekleştirilen ilk faktör analizi sonucunda 5 ifade faktör yükleri ,50'nin altında olması ve düşük yüklenme değerleri sebebiyle faktör analizinden çıkarılmıştır. Geriye kalan 23 ifade ile yapılan faktör analizi sonucunda Keyser-Meyer-Olkin testi sonucu örneklem yeterlilik değeri 0,921 bulunmuş ve bu değer faktör analizi için uygun bir değer olarak görülmüştür (Can, 2014: 303). Faktör analizinde korelasyon matrisinin yeterliliği ve önem düzeyi için Bartlett's Sphericity testi kullanılmıştır. Gerçekleştirilen faktör analizi sonucunda korelasyon matrisinin yeterliliği ve önem düzeyi sırasıyla ,000 ve 4121,783 olarak belirlenmiş ve faktör analizi yapmak için bu değerler kabul edilebilir bir değer olarak alınmıştır. Yapılan faktör analizi sonucu 4 boyut bulunmuş ve bu boyutlar kalite-duygusal, finansal-sosyal-epistemik, itibar ve düşük kalite olarak isimlendirilmiştir.

Faktör analizi sonucunda değişkenlere ait faktör yük değerleri 0,596 ve üzerinde olarak tespit edilmiştir. Verilerin analizinde varimax rotasyonu kullanılmıştır. Faktör analizinde, öz değerleri 1'in üzerinde olan veriler değerlendirmeye alınmıştır. Gerçekleştirilen faktör analizi sonucunda değişkenlerin 4 faktör altında toplandığı görülmektedir. Bu 4 faktör toplam varyansın \%70,103'ünü açıklamaktadır. Bu değerler 4 faktörün 23 değişken tarafından açıklanan varyansı açıklayabildiğini göstermektedir. Bundan sonraki algılanan değer ölçeği ile ilgili analizlerde bu 4 faktör kullanılmıştır. Orijinal ölçeğin 7 boyuttan oluşmasına rağmen gerçekleştirilen faktör analizi sonucunda bazı boyutların tek faktör altında toplanması iki çalışmanın farklı kişilere ve farklı bölgelerdeki otellerde uygulanması ile açıklanabilir. 
Tablo 4. Algılanan Değer Ölçeğine İlişkin Faktör Analizi

\begin{tabular}{|c|c|c|c|c|}
\hline & $\begin{array}{l}\text { Faktör } \\
\text { yükleri }\end{array}$ & Özdeğer & $\begin{array}{l}\text { Açıllanan } \\
\text { varyans }\end{array}$ & $\begin{array}{l}\text { Cronbach } \\
\text { Alpha }\end{array}$ \\
\hline Kalite-Duygusal & & 11,829 & 51,432 & 0,927 \\
\hline Bu otelde sunulan hizmetin kalitesi tutarlıdır. & 619 & & & \\
\hline Bu otelin hizmetleri iyi planlanmıştır. & ,726 & & & \\
\hline $\begin{array}{l}\text { Bu otel kabul edilebilir kalite standartlarına } \\
\text { sahiptir. }\end{array}$ & 664 & & & \\
\hline Bu otel istikrarlı bir şekilde hizmet sunar. & 669 & & & \\
\hline Bu otelin hizmetlerinden keyif alırım. & 662 & & & \\
\hline Bu otel bende kalma isteği yaratır. & ,707 & & & \\
\hline $\begin{array}{l}\text { Bu otel hizmetleri kullanma konusunda rahat } \\
\text { hissettirir. }\end{array}$ & ,711 & & & \\
\hline Bu otelde kalmak iyi hissettirir. & ,717 & & & \\
\hline Bu otel beni memnun eder. & 628 & & & \\
\hline Finansal-Sosyal-Epistemik & & 1,988 & 8,643 & 0,912 \\
\hline Bu otelin değeri ödenen paraya göredir. &, 596 & & & \\
\hline Bu otel ödediğim paraya göre iyi oteldi. & ,704 & & & \\
\hline Bu otel ekonomiktir. & ,760 & & & \\
\hline $\begin{array}{l}\text { Bu otel başkaları tarafından kabul görüldüğümü } \\
\text { hissetmemi sağlar. }\end{array}$ & ,746 & & & \\
\hline $\begin{array}{l}\text { Bu otel başkaları tarafından olumlu algılanmamı } \\
\text { destekler. }\end{array}$ & ,700 & & & \\
\hline $\begin{array}{l}\text { Bu otel başkaları üzerinde iyi bir izlenim } \\
\text { oluşturmamı sağlar. }\end{array}$ &, 548 & & & \\
\hline Bu otel bana otantik bir deneyim yaşatır. & 613 & & & \\
\hline Bu otelde yapabileceğim çok şey var. & 671 & & & \\
\hline İtibar & & 1.228 & 5,339 & 0,901 \\
\hline Bu otel saygın bir oteldir. & ,706 & & & \\
\hline $\begin{array}{l}\mathrm{Bu} \text { otelin hizmetleri iyi düşünülerek } \\
\text { tasarlanmıştır. }\end{array}$ & ,734 & & & \\
\hline Bu otelin statüsü vardır. & ,764 & & & \\
\hline Bu otel itibarlıdır. & ,729 & & & \\
\hline Düşük Kalite & & 1.078 & 4,689 & 0,947 \\
\hline $\begin{array}{l}\text { Genel olarak otel çalışanlarının sunduğu hizmet } \\
\text { kalitesi düşüktür. }\end{array}$ & ,956 & & & \\
\hline $\begin{array}{l}\text { Otel çalışanları taahhüt edilen hizmetleri söz } \\
\text { verdiği zamanda ve doğru şekilde yerine } \\
\text { getirmez. }\end{array}$ & ,965 & & & \\
\hline
\end{tabular}

\section{Hizmet Kalitesi Algılanan Değer ve Davranışsal Niyet Arasındaki İlişki}

Hizmet kalitesi algılanan değer ve davranışsal niyet boyutları arasındaki ilişkiye yönelik uygulanan Pearson korelasyon analizi sonuçları Tablo 5'te yer almaktadır. 
Tablo 5. Hizmet Kalitesi Algılanan Değer ve Davranışsal Niyet Arasındaki İlişkiye Ait Korelasyon Analizi Sonuçları

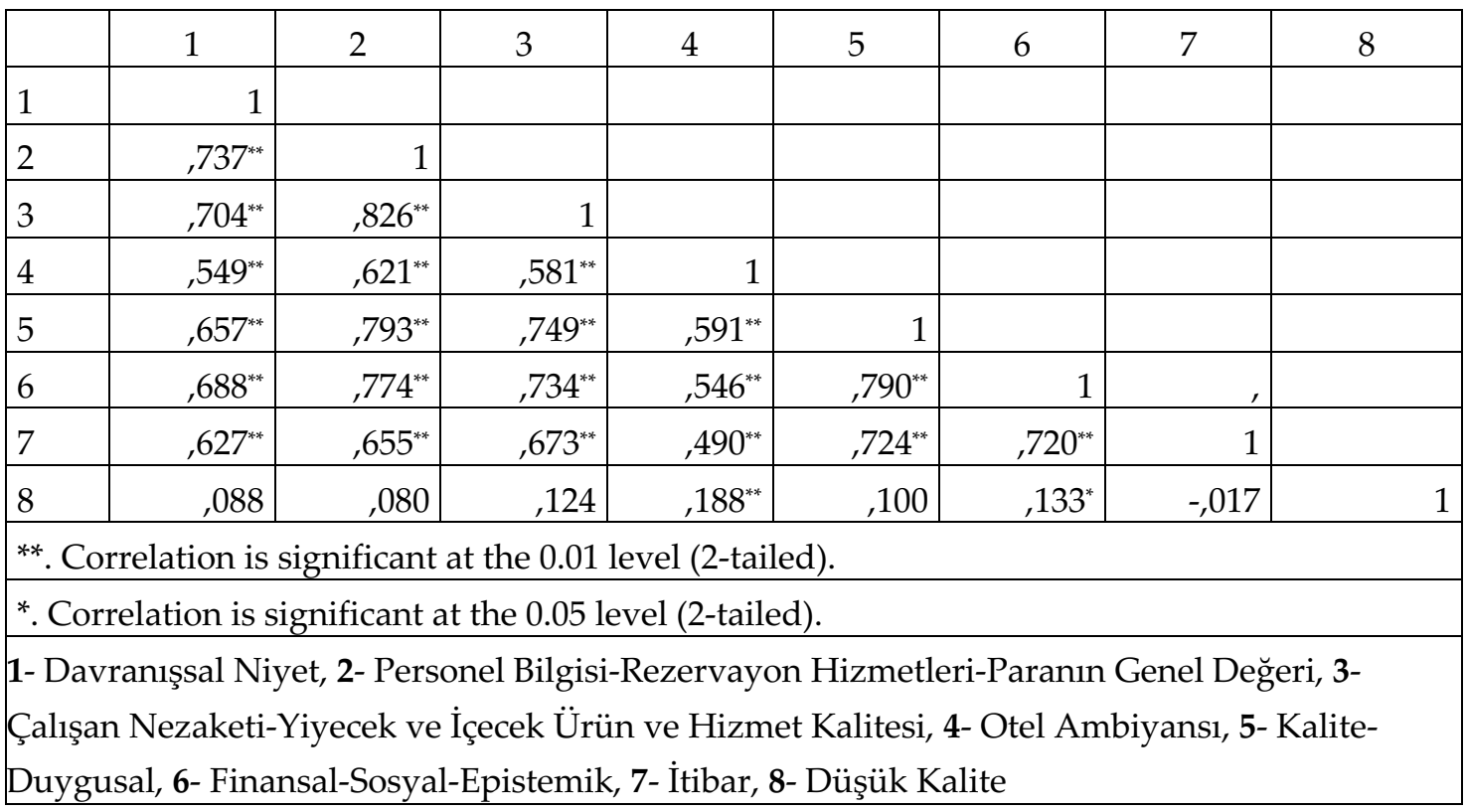

Tablo 5'te yer alan bulgular incelendiğinde Hizmet kalitesi boyutları ile davranışsal niyet arasındaki korelasyon katsayılarının tamamı pozitif yönlü ve ilişkiler istatistiki açıdan anlamlı bulunmuştur. Hizmet kalitesi boyutları ile algılanan değer boyutlarından düşük kalite boyutu dışındaki diğer boyutlar arasındaki korelasyon katsayılarının tamamı pozitif yönlü ve ilişkiler istatistiki açıdan anlamlı bulunmuştur. Yine aynı şekilde algılanan değer boyutlarından düşük kalite boyutu dışındaki diğer boyutlar ile davranışsal niyet arasındaki korelasyon katsayılarının tamamı pozitif yönlü ve ilişkiler istatistiki açıdan anlamlı bulunmuştur. Katsayılar incelendiğinde davranışsal niyet ile hizmet kalitesi boyutlarından personel bilgisi-rezervasyon hizmetleri-paranın genel değeri $(r=, 737)$, çalışan nezaketi-yiyecek ve içecek ürün ve hizmet kalitesi ( $\mathrm{r}=704)$, algilanan değer boyutlarından, kalite-duygusal ( $\mathrm{r}=657)$, finansal-sosyal-epistemik $(\mathrm{r}=688)$ ve itibar ( $\mathrm{r}=627)$ boyutları arasında yüksek düzeyde bir ilişki bulunmaktadır. Davranışsal niyet ile hizmet kalitesi boyutlarından otel ambiyansı ( $(=549)$ boyutu arasında orta düzeyde bir ilişki görülmektedir. Algılanan hizmet kalitesi ile algılanan değer boyutları arasındaki katsayılar değerlendirildiğinde; personel bilgisi-rezervasyon hizmetleri-paranın genel değeri ile kalite duygusal $(\mathrm{r}=$,793), finansal-sosyal-epistemik ( $\mathrm{r}=774)$, itibar $(\mathrm{r}=655)$ arasında yüksek düzeyde, çalışan nezaketi-yiyecek ve içecek ürün ve hizmet kalitesi ile kalite duygusal $(\mathrm{r}=, 749)$, finansalsosyal-epistemik ( $\mathrm{r}=734)$, itibar ( $\mathrm{r}=673)$ arasında yüksek düzeyde, Otel ambiyansı ile kalite duygusal $(\mathrm{r}=, 591)$, finansal-sosyal-epistemik $(\mathrm{r}=546)$, itibar $(\mathrm{r}=490)$ arasında orta düzeyde bir ilişki bulunmuştur. Algılanan değer boyutlarından düşük kalite ile hizmet kalitesi boyutlarından otel ambiyansı (r=188) arasında ise çok zayıf bir ilişki söz konusudur.

\section{Hizmet Kalitesinin ve Algılanan Değerin Davranışsal Niyet Üzerine Etkisi}

Regresyon analizinden önce verilerin regresyon analizi yapmaya uygun olup olmadığını tespit etmek için Durbin Watson, tolerans ve VIF değerleri incelenmiştir. Durbin Watson değerinin 1-3 arasında olması (Akbulut, 2010: 74), VIF değerlerinin 10'dan küçük tolerans değerlerinin ise 0,20 'dan büyük olması gerekmektedir (Can, 2014: 291). Tablo 6 ve Tablo 7 incelendiğinde verilerin otokorelasyon ve 
çoklu bağlantı sorunu olmadığı görülmektedir. Bu sonuçlar doğrultusunda verilerin çoklu doğrusal regresyon analizi yapmaya uygun olduğu tespit edilmiştir.

Tablo 6. Hizmet Kalitesi ile Davranışsal Niyet Arasındaki İlişkiye Ait Çoklu Doğrusal Regresyon Analizi Sonuçları

\begin{tabular}{lcccccc}
\hline & $\mathbf{B}$ & $\begin{array}{c}\text { Standart } \\
\text { Hata }\end{array}$ & $\mathbf{t}$ & $\mathbf{p}$ & Tolerance & VIF \\
\hline Sabit &, 569 &, 267 & 2,130 &, 034 & & \\
\hline $\mathbf{1}$ &, 588 &, 110 & 5,368 &, 000 &, 288 & 3,473 \\
\hline $\mathbf{2}$ &, 369 &, 104 & 3,550 &, 000 &, 310 & 3,222 \\
\hline $\mathbf{3}$ &, 144 &, 068 & 2,129 &, 034 &, 600 & 1,666 \\
\hline $\mathrm{R}=, 762$ & $\mathrm{R}^{2}=, 580$ & $\mathrm{~F}=102,668$ & $\mathrm{p}=, 000$ & Durbin Watson $=1,740$ & \\
\hline
\end{tabular}

\begin{tabular}{l} 
Bağımlı değişken: Davranışsal Niyet \\
\hline 1- Personel Bilgisi-Rezervasyon Hizmetleri-Paranın Genel Değeri, 2- Çalışan Nezaketi-Yiyecek \\
ve İçecek Ürün ve Hizmet Kalitesi, 3- Otel Ambiyansı
\end{tabular}

Tablo 6 incelendiğinde faktörler arasında oluşturulan çoklu regresyon modeli anlamlı bulunmuştur (F:102,668, p<0,01). Hizmet kalitesinin davranışssal niyet üzerinde \%58 oranında açıklayıcılığı bulunmaktadır. Tablo 6'ya göre hizmet kalitesi boyutlarının hepsinin bağımlı değişken olan davranışsal niyet üzerinde anlamlı bir etkisi bulunmaktadır $(p<0,05)$. Tablo 6 'da yer alan $B$ değerlerine göre davranışsal niyeti etkileyen en önemli faktör personel bilgisi-rezervasyon hizmetleri-paranın genel değeri faktördür. Bunu sırasıyla çalışan nezaketi-yiyecek ve içecek ürün ve hizmet kalitesi ve otel ambiyansı boyutları izlemektedir. Bu doğrultuda çalısmanın $\mathrm{H}_{3}$ hipotezi "hizmet kalitesinin davranışsal niyet üzerine etkisi vardır." desteklenmiştir.

Tablo 7. Algılanan Değer ile Davranışsal Niyet Arasındaki İlişkiye Ait Çoklu Doğrusal Regresyon Analizi Sonuçları

\begin{tabular}{lcccccc}
\hline & $\mathbf{B}$ & $\begin{array}{c}\text { Standart } \\
\text { Hata }\end{array}$ & $\mathbf{t}$ & $\mathbf{P}$ & Tolerance & VIF \\
\hline Sabit &, 046 &, 268 &, 172 &, 863 & & \\
\hline $\mathbf{1}$ &, 260 &, 103 & 2,533 &, 012 &, 314 & 3,180 \\
\hline $\mathbf{2}$ &, 460 &, 101 & 4,551 &, 000 &, 324 & 3,089 \\
\hline $\mathbf{3}$ &, 242 &, 087 & 2,780 &, 006 &, 395 & 2,532 \\
\hline $\mathbf{4}$ &, 013 &, 029 &, 449 &, 654 &, 952 & 1,050 \\
\hline $\mathrm{R}=, 724$ & $\mathrm{R}^{2}=, 524$ & $\mathrm{~F}=60,789$ & $\mathrm{p}=, 000$ & Durbin Watson=1,973 & \\
\hline Bağıml değişken: Davranışsal Niyet \\
\hline 1- Kalite-Duygusal, 2- Finansal-Sosyal-Epistemik, 3- İtibar, 4- Düşük Kalite \\
\hline \multicolumn{7}{l}{} \\
\hline
\end{tabular}

Tablo 7 incelendiğinde faktörler arasında oluşturulan çoklu regresyon modeli anlamlı bulunmuştur (F:126,148, p<0,01). Algılanan değer davranışsal niyet üzerinde \%52,4 oranında açılayıcilığı bulunmaktadır. Tablo 7'ye göre algılanan değere ait kalite duygusal, finansal-sosyal-epistemik ve itibar boyutlarının bağımlı değişken olan davranışsal niyet üzerinde anlamlı bir etkisi varken $(p<0,05)$, düşük kalite boyutunun davranışsal niyet üzerine anlamlı bir etkisinin olmadığı görülmektedir $(p>0,05)$. Tablo 7 'de yer alan B değerlerine göre davranışsal niyeti etkileyen en önemli faktör finansalsosyal-epistemik faktörüdür. Daha sonra sırasıyla kalite-duygusal ve itibar boyutları gelmektedir. Bu 
doğrultuda çalışmanın $\mathrm{H}_{2}$ hipotezi "Algılanan değerin davranışsal niyet üzerine etkisi vardır." kısmen desteklenmiştir. Düşük kalite algısının davranışsal niyeti etkilememesi müşterilerin algıladıkları diğer değer boyutlarını daha önemli görmelerinden kaynaklanabilir.

\section{Hizmet Kalitesinin Algılanan Değer Üzerine Etkisi}

Hizmet kalitesinin algılanan değer üzerine etkisini belirlemek üzere her bir algılanan değer boyutu bağımlı değişken olarak ele alınarak regresyon analizi gerçekleştirilmiştir. Regresyon analizinden önce verilerin regresyon analizi yapmaya uygun olup olmadığını tespit etmek için Durbin Watson, tolerans ve VIF değerleri incelenmiştir. Durbin Watson değerinin 1-3 arasında olması (Akbulut, 2010: 74), VIF değerlerinin $10^{\prime}$ dan küçük tolerans değerlerinin ise 0,20 'dan büyük olması gerekmektedir (Can, 2014: 291). Tablo 8, tablo 9, tablo 10 ve tablo 11 incelendiğinde verilerin otokorelasyon ve çoklu bağlantı sorunu olmadığı görülmektedir. Bu sonuçlar doğrultusunda verilerin çoklu doğrusal regresyon analizi yapmaya uygun olduğu tespit edilmiştir.

Tablo 8. Hizmet Kalitesi ile Algılanan Değer Kalite-Duygusal Boyutu Arasındaki İlişkiye Ait Çoklu Doğrusal Regresyon Analizi Sonuçları

\begin{tabular}{|c|c|c|c|c|c|c|}
\hline & B & $\begin{array}{l}\text { Standart } \\
\text { Hata }\end{array}$ & $\mathbf{t}$ & p & Tolerance & VIF \\
\hline Sabit & 121 & ,192 & 631 & ,528 & & \\
\hline 1 & ,535 & ,079 & 6,799 & , 000 & ,288 & 3,473 \\
\hline 2 & ,290 & ,075 & 3,881 & ,000 & ,310 & 3,222 \\
\hline 3 & 128, & 049, & 2,634 & 009, & 600, & 1,666 \\
\hline $\mathrm{R}=, 817$ & $\mathrm{R}^{2}=, 667$ & $\mathrm{~F}=148,135$ & $p=, 000$ & Durbin W & $=2,432$ & \\
\hline \multicolumn{7}{|c|}{ Bağımlı değişken: Kalite Duygusal } \\
\hline \multicolumn{7}{|c|}{$\begin{array}{l}\text { 1- Personel Bilgisi-Rezervayon Hizmetleri-Paranın Genel Değeri, 2- Çalışan Nezaketi-Yiyecel } \\
\text { ve İçecek Ürün ve Hizmet Kalitesi, 3- Otel Ambiyansı }\end{array}$} \\
\hline
\end{tabular}

Tablo 8 incelendiğinde faktörler arasında oluşturulan çoklu regresyon modeli anlamlı bulunmuştur (F:148,135, p<0,01). Hizmet kalitesinin kalite-duygusal üzerinde \%66,7 oranında açıklayıcilı̆̆ bulunmaktadır. Tablo 8'e göre hizmet kalitesi boyutlarının hepsinin bağımlı değişken olan kaliteduygusal üzerinde anlamı bir etkisi bulunmaktadır $(p<0,05)$. Bu doğrultuda çalışmanın Hıa hipotezi "Algilanan Hizmet Kalitesi Algılanan Değer Kalite-Duygusal Boyutunu Etkilemektedir." desteklenmiştir. Tablo 8' de yer alan B değerlerine göre kalite duygusalı etkileyen en önemli faktör personel bilgisi-rezervasyon hizmetleri- paranın genel değeri faktördür. Bunu sırasıyla çalışan nezaketi-yiyecek ve içecek ürün ve hizmet kalitesi ve otel ambiyansı boyutları izlemektedir.

Tablo 9 incelendiğinde faktörler arasında oluşturulan çoklu regresyon modeli anlamlı bulunmuştur (F:126,720, p<0,01). Hizmet kalitesinin finansal-sosyal-epistemik üzerinde \%63 oranında açıklayıcıllğ bulunmaktadır. Tablo 9'a göre hizmet kalitesi boyutlarından personel bilgisi-rezervasyon hizmetleri-paranın genel değeri ve çalışan nezaketi-yiyecek ve içecek ürün ve hizmet kalitesinin bağımlı değişken olan finansal-sosyal-epistemik üzerinde anlamlı bir etkisi bulunmaktadır $(p<0,05)$. Otel ambiyansı boyutunun ise anlamlı bir etkisi bulunmamaktadır $(p>0,05)$. Bu doğrultuda çalışmanın $\mathrm{H}_{1 \mathrm{~b}}$ hipotezi "Algılanan Hizmet Kalitesi Algılanan Değer Finansal-Sosyal-Epistemik Boyutunu Etkilemektedir.” Kısmen desteklenmiştir. Tablo 9'da yer alan B değerlerine göre finansal- 
sosyal-epistemiki etkileyen en önemli faktör personel bilgisi-rezervasyon hizmetleri- paranın genel değeri faktörüdür. Daha sonra çalışan nezaketi-yiyecek ve içecek ürün ve hizmet kalitesi boyutu gelmektedir. Otel ambiyansı genellikle kişinin iç dünyasına hitap ettiğinden özellikle kişinin otele ödediği paraya değip değmediğini ya da sosyal anlamda kişiyi tatmin edip etmemesini etkilememiş olabilir.

Tablo 9 Hizmet Kalitesi ile Algılanan Değer Finansal-Sosyal-Epistemik Boyutu Arasındaki İlişkiye Ait Çoklu Doğrusal Regresyon Analizi Sonuçları

\begin{tabular}{lcccccc}
\hline & $\mathbf{B}$ & $\begin{array}{c}\text { Standart } \\
\text { Hata }\end{array}$ & $\mathbf{t}$ & $\mathbf{p}$ & Tolerance & VIF \\
\hline Sabit &, 194 &, 203 &, 957 &, 339 & & \\
\hline $\mathbf{1}$ &, 542 &, 083 & 6,508 &, 000 &, 288 & 3,473 \\
\hline $\mathbf{2}$ &, 305 &, 079 & 3,861 &, 000 &, 310 & 3,222 \\
\hline $\mathbf{3}$ &, 074 &, 051 & 1,433 &, 153 &, 600 & 1,666 \\
\hline $\mathrm{R}=, 794$ & $\mathrm{R}^{2}=, 630$ & $\mathrm{~F}=126,720$ & $\mathrm{p}=, 000$ & Durbin Watson $=2,285$ & \\
\hline Bay
\end{tabular}

\section{Bağımlı değişken: Finansal-Sosyal-Epistemik}

1- Personel Bilgisi-Rezervasyon Hizmetleri-Paranın Genel Değeri, 2-Çalışan Nezaketi-Yiyecek ve İçecek Ürün ve Hizmet Kalitesi, 3- Otel Ambiyansı

Tablo 10 Hizmet Kalitesi ile Algılanan Değer İtibar Boyutu Arasındaki İlişkiye Ait Çoklu Doğrusal Regresyon Analizi Sonuçları

\begin{tabular}{lcccccc}
\hline & $\mathbf{B}$ & $\begin{array}{c}\text { Standart } \\
\text { Hata }\end{array}$ & $\mathbf{t}$ & $\mathbf{p}$ & Tolerance & VIF \\
\hline Sabit &, 654 &, 250 & 2,615 &, 010 & & \\
\hline $\mathbf{1}$ &, 313 &, 103 & 3,047 &, 003 &, 288 & 3,473 \\
\hline $\mathbf{2}$ &, 447 &, 097 & 4,589 &, 000 &, 310 & 3,222 \\
\hline $\mathbf{3}$ &, 095 &, 063 & 1,497 &, 136 &, 600 & 1,666 \\
\hline $\mathrm{R}=, 699$ & $\mathrm{R}^{2}=, 489$ & $\mathrm{~F}=71,052$ & $\mathrm{p}=, 000$ & Durbin Watson $=2,100$ & \\
\hline
\end{tabular}

Bağımlı değişken: İtibar

1- Personel Bilgisi-Rezervasyon Hizmetleri-Paranın Genel Değeri, 2- Çalışan Nezaketi-Yiyecek ve İçecek Ürün ve Hizmet Kalitesi, 3- Otel Ambiyansı

Tablo 10 incelendiğinde faktörler arasında oluşturulan çoklu regresyon modeli anlamlı bulunmuştur (F:71,052, p<0,01). Hizmet kalitesinin itibar boyutu üzerinde $\% 48,9$ oranında açıklayıcılığ bulunmaktadır. Tablo 10'a göre hizmet kalitesi boyutlarından personel bilgisi-rezervayon hizmetleri-paranın genel değeri ve çalışan nezaketi-yiyecek ve içecek ürün ve hizmet kalitesinin bağımlı değişken olan itibar üzerinde anlamlı bir etkisi bulunmaktadır $(p<0,05)$. Otel ambiyansı boyutunun ise anlamlı bir etkisi bulunmamaktadır ( $>>0,05)$. Bu doğrultuda çalışmanın Hıc hipotezi "Algılanan Hizmet Kalitesi Algılanan Değer İtibar Boyutunu Etkilemektedir." Kısmen desteklenmiştir. Tablo 10'da yer alan B değerlerine göre itibarı etkileyen en önemli faktör alışan nezaketi-yiyecek ve içecek ürün ve hizmet kalitesi faktörüdür. Daha sonra çalışan personel bilgisirezervasyon hizmetleri- paranın genel değeri boyutu gelmektedir. Otel işletmesinin fiziki görünüşü, müşteriye yaşattığı görsellik gibi özellikler müşteriler tarafından itibarı etkileyen faktörler olarak görülmemiş olabilir. Otel içerisindeki fiziki donanım gibi unsurlar tek başına işletmenin itibarını arttırıcı ya da azaltıı bir faktör olarak görülmeyebilir. 
Tablo 11. Hizmet Kalitesi ile Algılanan Değer Düşük Kalite Boyutu Arasındaki İlişkiye Ait Çoklu Doğrusal Regresyon Analizi Sonuçları

\begin{tabular}{lcccccc}
\hline & $\mathbf{B}$ & $\begin{array}{c}\text { Standart } \\
\text { Hata }\end{array}$ & $\mathbf{t}$ & $\mathbf{p}$ & Tolerance & VIF \\
\hline Sabit & 1,659 &, 672 & 2,468 &, 014 & & \\
\hline $\mathbf{1}$ &, 366 &, 275 & 1,327 &, 186 &, 288 & 3,473 \\
\hline $\mathbf{2}$ &, 303 &, 261 & 1,158 &, 248 &, 310 & 3,222 \\
\hline $\mathbf{3}$ &, 424 &, 170 & 2,486 &, 014 &, 600 & 1,666 \\
\hline $\mathrm{R}=, 208$ & $\mathrm{R}^{2}=, 043$ & $\mathrm{~F}=3,360$ & $\mathrm{p}=, 020$ & Durbin Watson $=1,174$ & \\
\hline
\end{tabular}

\begin{tabular}{l}
\hline Bağımlı değişken: Düşük Kalite \\
\hline 1- Personel Bilgisi-Rezervayon Hizmetleri-Paranın Genel Değeri, 2- Çalışan Nezaketi-Yiyecek \\
ve İçecek Ürün ve Hizmet Kalitesi, 3- Otel Ambiyansı
\end{tabular}

Tablo 11 incelendiğinde faktörler arasında oluşturulan çoklu regresyon modeli anlamlı bulunmamıştır (F:3,360, p>0,01). Bu doğrultuda çalışmanın Hid hipotezi "Algılanan Hizmet Kalitesi Algılanan Değer Düşük Kalite Boyutunu Etkilemektedir." desteklenmemiştir.

\section{SONUÇ ve ÖNERILER}

Dünyada yaşanan önemli gelişmeler doğrultusunda pazarlama alanında da bazı değişimler yaşanmaktadır. İşletmeler önceleri sadece satış odaklı pazarlamaya eğilimliyken, günümüzde ise müşteri odaklı pazarlama eğilimi göstermektedirler. Geleneksel pazarlamanın yerine geçen çağdaş pazarlama yaklaşımı ile işletmeler için önemli olan işletmeye bağlı müşterilerin var olmasıdır (Baykal ve Ayyıldız, 2020: 1248). Günümüz sert rekabet koşulları içerisinde işletmeler bu çağdaş pazarlama yaklaşımlarını kullanarak rakiplerinin önüne geçmeye çalışmaktadırlar. Ancak bu pazarlama yaklaşımları yanında işletmelerin müşterilerinin duygularına hitap etmeleri gerekmektedir. Bunun en önemli yolu ise işletmelerin sundukları hizmetin kalitesidir. Özellikle otel işletmelerinde verilen hizmet ön planda yer almaktadır. Otel işletmeleri sundukları hizmet kalitesi ile müşterilerinin kısa olan tatillerini mutluluğa ya da mutsuzluğa çevirebilmektedirler. Otel işletmeleri sunmuş oldukları yüksek hizmet kalitesi ile birlikte doğrudan müşterilerinin otel işletmesinde algıladıkları değere hitap etmektedirler. Bu durum müşterilerin davranışsal niyetlerinde olumlu etkilemektedir. Dolayısıyla algılanan hizmet kalitesinin hem algılana değer hem de davranışsal niyet üzerinde etkisi bulunmaktadır. Ayrıca algılana değerde müşterilerin davranışsal niyetlerini etkileyebilmektedir. Bu doğrultuda bu çalışmanın temel amacı algılanan hizmet kalitesinin algılanan değer ve davranışsal niyet üzerine etkisini ortaya koymaktır. Bu temel amaca ek olarak algılanan değerin davranışsal niyet üzerine etkisini ortaya koymak çalışmanın alt amacı olarak belirlenmiştir.

Çalışmaya toplam 388 kişi katılmıştır. Katılımcıların çoğunluğu kadın, 26-35 yaş aralığında, üniversite mezunu ve yabancı turistlerden oluşmaktadır. Katılımcıların çoğunluğu çalışmanın yapıldığı andaki konakladıkları otelde ilk defa konaklamaktadırlar. Çalışma kapsamında öncelikle algılanan hizmet kalitesi, algılanan değer ve davranışsal niyet ölçeklerine güvenilirlik ve faktör analizi uygulanmıştır. Davranışsal niyet ölçeği Ali (2015) tarafından kullanılan ölçektir. Öncelikle bu ölçeğe güvenilirlik analizi uygulanmış ve ölçeğin oldukça güvenilir olduğu tespit edilmiştir. Gerçekleştirilen faktör analizi sonucunda Ali (2015) kullanmış olduğu ölçeğe benzer şekilde ifadelerin tek boyut altında toplandığı görülmüştür. Hizmet kalitesi ölçeği yine Ali (2015) tarafından kullanılan ölçektir. Ali (2015) tarafından gerçekleştirilen çalışmada hizmet kalitesi ölçeği 5 boyuttan oluşmaktadır. Çalışma kapsamında gerçekleştirilen güvenilirlik analizi sonucu 
ölçeğin oldukça güvenilir olduğu görülmüştür. Gerçekleştirilen faktör analizi sonucunda ise Ali (2015)'den farklı olarak ölçek 3 boyuttan oluşmaktadır. Gerçekleştirilen faktör analizi sonucunda bazı boyutların birleştiği görülmüş ve Ali (2015) yapmış olduğu çalışmadaki hizmet kalitesi boyutlarının isimleri kullanılarak faktörler isimlendirilmiştir. Algılanan değer ölçeği Küpeli (2014) tarafından kullanılan ölçektir. Ölçeğin orijinali 6 boyuttan oluşmaktadır. Gerçekleştirilen güvenilirlik analizi sonucu ölçeğin güvenilir olduğu sonucuna varılmış ve faktör analizi gerçekleştirilmiştir. Yapılan faktör analizi sonucu orijinalden farklı olarak ifadelerin 4 boyut altında toplandığı tespit edilmiştir. Gerçekleştirilen faktör analizi sonucunda bazı boyutların birleştiği görülmüş ve Küpeli (2014) yapmış olduğu çalışmadaki hizmet kalitesi boyutlarının isimleri kullanılarak faktörler isimlendirilmiştir.

Çalışma kapsamında gerçekleştirilen korelasyon analizi sonucunda hizmet kalitesi ile algılanan değer ve davranışsal niyet arasındaki ilişkiler ortaya konmuştur. Korelasyon katsayılar doğrultusunda davranışsal niyet ile hizmet kalitesi boyutlarından personel bilgisi-rezervasyon hizmetleri-paranın genel değeri, çalışan nezaketi-yiyecek ve içecek ürün ve hizmet kalitesi arasında yüksek düzeyde bir etki söz konusudur. Aynı şekilde algılanan değer boyutlarından, kalite-duygusal, finansal-sosyal-epistemik ve itibar boyutları arasında yüksek düzeyde bir etkileşim bulunmaktadır. Davranışsal niyet ile hizmet kalitesi boyutlarından otel ambiyansı boyutu arasında orta düzeyde bir etkileşim görülmektedir. Algılanan hizmet kalitesi ile algılanan değer boyutları arasındaki katsayılar değerlendirildiğinde; personel bilgisi-rezervasyon hizmetleri-paranın genel değeri ile kalite duygusal, finansal-sosyal-epistemik, itibar arasında yüksek düzeyde, çalışan nezaketi-yiyecek ve içecek ürün ve hizmet kalitesi ile kalite duygusal, finansal-sosyal-epistemik, itibar arasında yüksek düzeyde, Otel ambiyansı ile kalite duygusal, finansal-sosyal-epistemik, itibar arasında orta düzeyde bir etkileşim bulunmuştur. Algılanan değer boyutlarından düşük kalite ile hizmet kalitesi boyutlarından otel ambiyansı arasında ise çok zayıf bir ilişki söz konusudur.

Hizmet kalitesi ve davranışsal niyet arasında gerçekleştirilen regresyon analizi sonuçlarına göre davranışsal niyeti etkileyen en önemli faktör personel bilgisi-rezervasyon hizmetleri-paranın genel değeri faktördür. Bunu sırasıyla çalışan nezaketi-yiyecek ve içecek ürün ve hizmet kalitesi ve otel ambiyansı boyutları izlemektedir. Ali (2015) yapmış olduğu çalışmada hizmet kalitesi boyutları ile davranışsal niyet arasında pozitif yönlü ilişkiler olduğunu ortaya koymuştur. Algılanan değer ile davranışsal niyet arasında gerçekleştirilen regresyon analizi sonucunda ise algılanan değerin düşük kalite boyutu dışındaki tüm boyutlarının davranışsal niyeti etkilediği görülmektedir. Küpeli (2014) yapmış olduğu çalışmada da algılanan değer boyutlarının davranışsal niyeti etkilediğini ortaya koymaktadır. Algılanan değer ile algılanan hizmet kalitesi boyutları arasında gerçekleştirilen regresyon analizi sonucunda sadece algilanan değerin düşük kalite boyutu ile algilanan hizmet kalitesi boyutları arasındaki regresyon modeli istatistiki açıdan anlamlı bulunmamıştır. Hizmet kalitesi boyutlarının hepsinin algılanan değer boyutlarından kalite-duygusal üzerinde anlamlı bir etkisi bulunurken, hizmet kalitesi boyutlarından personel bilgisi-rezervasyon hizmetleri-paranın genel değeri ve çalışan nezaketi-yiyecek ve içecek ürün ve hizmet kalitesinin algılanan değer boyutlarından finansal-sosyal-epistemik üzerinde anlamlı bir etkisi bulunmaktadır. Ayn şekilde hizmet kalitesi boyutlarından personel bilgisi-rezervasyon hizmetleri-paranın genel değeri ve çalışan nezaketi-yiyecek ve içecek ürün ve hizmet kalitesinin algılanan değer itibar boyutu üzerinde anlamlı bir etkisi bulunmaktadır. Burada ilginç sonuçlar arasında algılanan değer düşük kalite boyutunun davranışsal niyeti etkilememesi ve hizmet kalitesi ile bu boyut arasındaki modelin anlamsız çıması. Bu durum düşük kalite boyutu işletmenin kalitesinin olumsuzlukları ile ilgilidir. $\mathrm{Bu}$ olumsuz kalite ifadeleri davranışsal niyeti etkilemediği gibi hizmet kalitesi ile düşük kalite arasında bir etkileşim ortaya çıkarmamış olabilir. 
Sonuç olarak hizmet kalitesi ve algılanan değer boyutları ile davranışsal niyet arasında pozitif yönlü anlamlı ilişkiler söz konusudur. Bu nedenle tüm otel işletmelerinin rekabet açısından hizmet kalitesi ve müşterilerin algıladıkları değeri rekabet avantajı unsuru olarak görebilirler. Çalışmanın en önemli kısıtları arasında çalışmanın Kuşadası'ndaki 5 yıldızlı otel işletmeleri müşterilerine uygulanması bulunmaktadır. Bu nedenle sonraki çalışmalarda farklı işletmelerin müşterilerine gerçekleştirilebileceği gibi farklı bölgelerdeki işletmelerde de bu çalışmanın gerçekleştirilmesi ilgili literatüre katkı sağlayacaktır. Ayrıca otel işletmeleri verdikleri hizmetin kalitesinin müşteriler tarafından nasıl algılandığını ve müşterilerinin işletmelerinin değerini nasıl algıladıklarını ortaya koymak için ölçekleri kendileri uygulayarak eksik yönlerini giderme yoluna gidebilirler.

\section{KAYNAKÇA}

Akbulut, Y. (2010). Sosyal Bilimlerde SPSS Uygulamaları, İstanbul: İdeal Kültür ve Yayıncllk.

Ali, F. (2015). Service Quality as a Determinant of Customer Satisfaction and Resulting Behavioural Intentions: A SEM Approach Towards Malaysian Resort Hotels, Turizam, 67(1): 3751.

Ali, F., Omar, R. and Amin, M. (2013). An Examination of the Relationships Between Physical Environment, Perceived Value, Image and Behavioural Intentions: A SEM Approach Towards Malaysian Resort Hotels, Journal of Hotel and Tourism Management, 27(2): 9-26.

Ali, F., Khan, A. S. and Rehman, F. A. M. S. (2012). An Assessment of the Service Quality Using Gap Analysis: A study Conducted at Chitral, Pakistan, Interdisciplinary Journal of Contemporary Research in Business, 4(3): 259-266.

Altunışık, R., Coşkun, R., Bayraktaroğlu, S. ve Yıldırım, E. (2005). Sosyal Bilimlerde Araştırma Yöntemleri SPSS Uygulamalı (4. Baskl), Adapazarı: Sakarya Kitabevi.

Amin, M., Yahya, Z., Ismayatim, W. F. A., Nasharuddin, S. Z. and Kassim, E. (2013). Service Quality Dimension \& Customer Satisfaction: An Empirical Study in the Malaysian Hotel İndustry. Services Marketing Quarterly, 34(2): 115-125.

Arulkumar, S. (2015). Service Quality Measurement in Hotels A Gap Analysis Approach, Veis Management Journal, 1(2): 52-62.

Bashir, S., Khwaja, M. G., Turi, J. A. and Toheed, H. (2019). Extension of Planned Behavioral Theory to Consumer Behaviors in Green Hotel, Heliyon, 5(12): 1-8.

Baş, M. ve Artuğer, S. (2018). Algılanan Otel İmajının Davranışsal Niyetler Üzerine Etkisi: Marmaris'teki 5 Yıldızlı Otellerde Bir Araştırma, Uluslararası Sosyal Araştırmalar Dergisi, 11(61): 760-768.

Bauer, H. H., Falk, T. and Hammerschmidt, M. (2006). eTransQual: A Transaction Process-Based Approach for Capturing Service Quality in Online Shopping, Journal of Business Research,59:866875.

Baykal, M. ve Ayyıldız A. Y., (2020). Veri Tabanlı Pazarlama Faaliyetlerinin Müşteri Sadakatine Etkisi: Kuşadası'ndaki 4 ve 5 Yıldızlı Otel Yöneticileri Üzerine Bir Uygulama, Journal of Tourism and Gastronomy Studies, 8(2): 1247-1268.

Bloemer, J., Ruyter, K. D. and Wetzels, M. (1999). Linking Perceived Service Quality and Service Loyalty: A Multi-Dimensional Perspective, European Journal of Marketing, 33(11/12): 1082-1106. 
Can, A. (2014). SPSS ile Bilimsel Araştırma Sürecinde Nicel Veri Analizi (2. Baskı), Ankara: Pegem Akademi.

Chen, C.-F. and Chen, F.-S. (2010). Experience Quality, Perceived Value, Satisfaction and Behavioral Intentions for Heritage Tourists, Tourism Management, 31: 29-35.

Cronin, J. and Taylor, S. (1992). Measuring Service Quality: A Reexamination \& Extension. Journal of Marketing, 56(3): 55-68.

Cronin, Jr J.J., Brady, M.K. and Hult, G.T.M. (2000). Assessing the Effects of Quality, Value and Customer Satisfaction on Consumer Behavioral Intentions in Service Environment, Journal of Retailing, 76(2):193-218.

Dabholkar, P. A., Shepherd, C. D. and Thorpe, D. I. (2000). A Comprehensive Framework for Service Quality: An Investigation of Critical Conceptual and Measurement Issues Through a Longitudinal Study, Journal of Retailing, 6 (2): 139-173.

Ghobadian, A., Speller S. and Jones, M. (1994). Service Quality Concepts and Models, International Journal of Quality \& Reliability Management, 11 (9): 43-66.

Graf, A. and Maas, P. (2008). Customer Value from a Customer Perspective: A Comprehensive Review,Journal Für Betriebswirtschaft, 58 (1): 1-20.

Gronroos, C. (1984). A Service Quality Model and its Marketing Implications. European Journal of Marketing, 18(4): 36-44.

Gwin, C. F. (2009). The Impact of Trust and Brand Relationship Quality on Perceived Value and Loyalty in a Consumer Goods Environment, SWDSI proceedings 528-537.

Haddad, R. E., Hallak, R. and Assaker, G. (2015). Price Fairness Perceptions and Hotel Customers' Behavioral Intentions, Journal of Vacation Marketing, 21(3): 262-276.

Han, H. and Kim, W. (2009). Outcomes of Relational Benefits: Restaurant Customers' Perspective, Journal of Travel \& Tourism Marketing, 26(8): 820-835.

Hu, H., Kandampully, J. and Juwaheer, T. D. (2009). Relationships and Impacts of Service Quality, Perceived Value, Customer Satisfaction and İmage: An Empirical Study. The Service Industries Journal, 29(2): 111-125.

Ishaq, M. I. (2012). Perceived Value, Service Quality, Corporate Image and Customer Loyalty: Empirical Assessment from Pakistan, Serbian Journal of Management, 7: 25-36.

Jani, D. and Han, H. (2011). Investigating the Key Factors Affecting Behavioral Intentions: Evidence from a Full-Service Restaurant Setting, International Journal of Contemporary Hospitality Management, 23(7): 1000-1018.

Kauar, G. and Gupta, S. (2012). Consumers' Behavioral Intentions Toward Self-Service Technology in the Emerging Markets, Journal of Global Marketing, 25:(5): 241-261.

Kuo, Y. F., Wu, C. M., and Deng, W. J. (2009). The relationships Among Service Quality, Perceived Value, Customer Satisfaction, and Post-Purchase Intention in Mobile Value-Added Services, Computers in Human Behavior, 25(4): 887-896.

Küpeli, T. Ş. (2014). Algılanan Risk ve Algılanan Değer Arasındaki Illişkilerin Otel Müşterileri Üzerinde İncelenmesi, Yayınlanmamış Yüksek Lisans Tezi. Hacettepe Üniversitesi, Ankara.

Ladhari, R., (2009). Service Quality, Emotional Satisfaction, and Behavioural Intentions: A Study in the Hotel Industry, Managing Service Quality, 19 (3): 308-331. 
LeBlanc, G. and Nguyen, N. (1999). Listening to the Customer's Voice: Examining Perceived Service Value Among Business College Students, The International Journal of Educational Management, 13(4): 187-198.

Lee, J., Graefe A. R. and Burns, R. C. (2004). Service Quality, Satisfaction, and Behavioral Intention Among Forest Visitors, Journal of Travel \& Tourism Marketing, 17(1): 73-82.

Markovic, S. and Raspor, S. (2010). Measuring Perceived Service Quality Using SERVQUAL: A Case Study of the Croatian Hotel Industry, Management, 5(3): 195-209.

Mei, A. W. O., Dean, A. M. and White, C. J. (1999). Analyzing Service Quality in the Hospitality Industry, Managing Service Quality, 9: 136-143.

Özdamar, K. (1999). Paket Programlar ile İstatistiksel Veri Analizi (2. Baskl), Eskişehir: Kaan Kitabevi.

Parasuraman, A., Zeithaml, V. A. and Berry, L. L. (1985). A Conceptual Model of Service Quality and its Implication for Future Research, Journal of Marketing, 49: 41-50.

Parasuraman, A., Zeithaml, V. and Berry, L. (1988). SERVQUAL: A Multiple-Item Scale for Measuring Consumer Perceptions of Service Quality, Journal of Retailing: 64(1), 12-40.

Saleh, F. and Ryan, C. (1991). Analyzing Service Quality in the Hospitality Industry Using SERVQUAL, The Service Industries Journal, 11(3): 324-346.

Sánchez, J., Callarisa, L., Rodríguez, R., and Moliner, M. (2006). Perceived Value of the Purchase of a Tourism Product, Tourism Management, 27(3): 394-409.

Sánchez-Fernández, R., and Iniesta-Bonillo, M. Á. (2007). The Concept of Perceived Value: A Systematic Review of the Research, Marketing Theory, 7(4): 427-451.

Sevgi, O. O. ve Paksoy, M. (2018). Otel İşletmelerinde Yabancı Turistlerin Hizmet Kalitesi Algısının Servqual Yöntemle Ölçülmesine Yönelik Bir Araştırma, Tüketici ve Tüketim Araştırmaları Dergisi / Journal of Consumer and Consumption Research, 10(1): 53-77.

Sheth, J., Newman, B., and Gross, B. (1991). Why We Buy What We Buy: A Theory of Consumption Values, Journal of Business Research, 22(2): 159-170.

Sweeney, J., and Soutar, G. (2001). Consumer Perceived Value: The Development of a Multiple Item Scale, Journal of Retailing, 77: 203-220.

Şimşek, A. (2012). Araştırma Modelleri, (Editör) Şimşek, A.: Sosyal Bilimlerde Araştırma Yöntemleri içinde, (ss.80-107) Eskişehir: Anadolu Üniversitesi Web-Ofset Tesisleri.

Tabachnick, B. G. and Fidell, L. S. (2013). Using Multivariate Statistics (6th ed.), Boston: Pearson.

Tam, J.L.M. (2000). The Effects of Service Quality, Perceived Value and Customer Satisfaction on Behavioral İntentions, Journal of Hospitality and Leisure Marketing, 6(4): 31-44.

Theodorakis, N.D., and Alexandris, K. (2008). Can Service Quality Predict Spectators' Behavioral Intentions in Professional Soccer? Managing Leisure, 13: 162-178.

Türkmendağ, T. ve Köroğlu, A. (2018). Algılanan Değerin Marka Kişiliği Üzerine Etkisi, Uluslararası Yönetim Ikktisat ve İşletme Dergisi, 14(4): 1121-1146.

Vijayadurai, J. (2008). Service Quality, Customer Satisfaction and Behavioural Intention in Hotel Industry, Journal of Marketing \& Communication, 3(3): 14-26.

Wu, H. C. (2014). The Effects of Customer Satisfaction, Perceived Value, Corporate Image and Service Quality on Behavioral Intentions in Gaming Establishments, Asia Pacific Journal of Marketing and Logistics, 26(4): 540-565. 
Yu H. S., Zhang J. J., Kim D. H., Chen K. K., Henderson C., Min S. D. and Huang H. (2014). Service Quality, Perceived Value, Customer Satisfaction, and Behavioral Intention Among Fitness Center Members Aged 60 Years and Over, Social Behavior and Personality: an international journal, 42(5): 757-767.

Zeithaml, V., Berry, L. and Parasuraman, A. (1996). The Behavioural Consequences of Service Quality, Journal of Marketing, 60(2): 31-46.

Zeithaml, V. A. (1988). Consumer Perceptions of Price, Quality, and Value: A Means-End Model and Synthesis of Evidence, Journal of Marketing, 52(3): 2-22. 